\title{
New occurrence of eclogitic continental rocks in NW Himalaya: The Stak massif in northern Pakistan
}

\author{
Stéphane Guillot, ${ }^{* 1}{ }^{1}$ icolas Riel ${ }^{1}$, Kéiko Hattori ${ }^{2}$, Serge Desgreniers ${ }^{3}$, Yann Rolland ${ }^{4}$, \\ Jérémie Van Melle ${ }^{1}$, Mohamad Latif ${ }^{5}$, Allah B Kausar ${ }^{5}$ and Arnaud Pêcher ${ }^{1}$ \\ 1 University of Grenoble, OSUG - CNRS, BP 53, 38041 Grenoble cedex 9, FRANCE \\ 2 University of Ottawa, Dept of Earth Sciences, Ottawa, Ontario, CANADA K1N 6N5 \\ 3 University of Ottawa, Dept of Physics, Ottawa, Ontario, CANADA K1N 6N5 \\ ${ }^{4}$ University of Nice, Geosciences Azur - CNRS, 06108 Nice Cedex 02, FRANCE \\ 5 Geological Survey of Pakistan-Northern Area, Plot N . 84, H-8/1, Islamabad, PAKISTAN \\ * For correspondence, email: sguillot@uif-grenoble.fr
}

Three occurrences of ultrahigh pressure (UHP) rocks have been recognized along the Himalayan belt. In southern Tibet, Yang et al. (2007) documented diamond- and coesitebearing chromitites from the Lobuosa ophiolite in the Indus-Tsangpo Suture zone (ITSZ). Coesite-bearing eclogites are reported in the Tso Morari and Kaghan massifs in NW Himalaya (O'Brien et al. 2001, Mukherjee et al. 2003 2005) in the ITSZ of the Main Mantle Thrust (MMT). The latter occurrences are the products of the subduction of the margin of the Indian continent between 57 and $44 \mathrm{Ma}$ (Leech et al. 2005, Parrish et al. 2006, Guillot et al. 2008). We report a new occurrence of eclogitic rocks from the Stak area where pyroxenite boudins with a retrogressed eclogitic assemblage were described by Le Fort et al. in 1997. This massif east of the Nanga Parbat-Haramosh anticline consists of garnetbearing orthogneisses, metasediments, and marbles intruded by dykes of boudinaged garnet-bearing metabasites. The metabasites have similar chemical composition as the basalts of the Panjal Traps and this association of the metabasites with metasediments suggest that the rocks represent the western margin of the Indian continent, similar to the UHP massifs at Kaghan (Chaudhry and Ghazanfar 1987) and Tso Morari (Guillot et al. 1997). The rocks in the Stak area have undergone at least two phases of folding. The youngest event is defined by NE oriented steep folds (up to $100 \mathrm{~m}$ in size) with axial plane dipping $\sim 60^{\circ}$ towards the NW. Asymmetrical folds indicate the top verging to the SE, which is likely related to the exhumation of the Nanga Parbat-Haramosh block (Argles and Edwards 2002). The deformation of the MMT also affected the area, which resulted in alternating layers of weakly metamorphosed rocks of the Ladakh arc and strongly metamorphosed Indian continental rocks.

The Stak massif contains well preserved eclogitic assemblage; garnet (Pyr34), omphacite (Jd46), phengite, Ca carbonate (most likely aragonite). The presence of coesite is suspected because the peak metamorphic condition is in the stability field of coesite, greater than $2.7 \mathrm{GPa}$, based on the bulk and garnet compositions. Rims of garnet contain inclusions of phengite and dolomite, clinopyroxene (Jd24) and plagioclase (Ab80). Omphacite in the matrix is altered to a symplectic mixture of $\mathrm{Na}-\mathrm{Ca}$ clinopyroxene (Jd18) and albite, indicating that the retrogression under eclogitic conditions at $\sim 1.8 \pm 0.1 \mathrm{GPa}$ and $650-700^{\circ} \mathrm{C}$. The late folding developed under amphibolitic facies conditions as marked by pargasitic amphibole, biotite and ilmenite and later the crystallization of hornblende. The assemblages indicate that the folding took place during a pressure decrease from 11 to $8 \mathrm{kbar}$ and a temperature decrease from 700 to $600^{\circ} \mathrm{C}$. Finally late localized millimetric shear bands defined by calcite and chlorite developed at the ductile-brittle transition under greenschist facies conditions.

A few Ar-Ar biotite ages have been obtained in this study, and the data suggest that the Stak massif was cooled below $350^{\circ} \mathrm{C}$ before 20- $10 \mathrm{Ma}$, which corresponds to the exhumation of the Nanga Parbart Haramosh anticline (Zeitler et al. 2001). The Stak massif shares many features with the Kaghan massif including lithologies, location in the MMT and the mineral chemistry. The similarities suggest that the Stak-Kaghan massifs were possibly once a continuous UHP unit and later separated by the PlioMiocene uplift of the Nanga Parbat Haramosh block. If this hypothesis is correct, the size of the Kaghan-Stak UHP massif $\left(>500 \mathrm{~km}^{2}\right)$ is comparable to those of the Western Gneiss region of Norway and the Dabie-Sulu region in China. This will be tested by the data of our on-going studies including new microRaman spectometry, SHRIMP ages of zircon and Ar-Ar ages of amphibole, biotite and white micas.

\section{References}

Argles TW and MA Edwards. 2002. Journal of Structural Geology 24: 1327-1344

Chaudhry MN and M Ghazanfar. 1987. Geological Bulletin University of Punjab 22: 13-57

Guillot S et al. 1997. Contribution to Mineralogy and Petrology 128: 197-212

Guillot S et al. 2008., Tectonophysics: doi:10.1016/j.tecto.2007.11.059

Kaneko Y et al. 2003. Journal of Metamorphic Geology 21: 589-599

Le Fort P et al. 1997. Compte Rendus de l'Académie des Sciences, Paris 325: 773-778

Leech ML et al. 2005. Earth and Planet Science Letters 234: 83-97

Mukheerjee B et al. 2005. Géologie Alpine 44: 136

Mukheerjee B et al. 2003. International Geology Review 45: 49-69

O’Brien P et al. 2001. Geology 29: 435-438

Parrish R et al. 2006. Geology 34: 989-992

Yang JS et al. 2007. Geology 35: 875-878

Zeitler PK et al. 2001. Tectonics 20: 712-728 